\title{
Post COVID-19 - Individual Impact and Global Economy Recovery Predicament
}

\author{
Haoyu Zhao
}

Chase Collegiate School, Waterbury, 06708, U.S

\section{8@qq.com}

\section{Abstract:}

2020 has not been started as expected. We lost our treasured hero, Kobe Bryant, Australia has also suffered from natural disasters, but the worst is when the virus called the COVID-19 came to life and a global pandemic started since the beginning of the year. The virus was at first a blind spot to us, no one recognize how deadly and huge impact it can cause to our society. But it turns out to be a large-scale, highly contagious virus, which has caused great lose for humans.

Keywords: COVID-19, Infection, Mortality Rate.

\section{Introduction}

Back in 2019 when it was first discovered in Wuhan, China, the government officials and health practitioners did not pay much attention of COVID-19, because the new coronavirus does not have a very high mortality rate like Ebola virus or SARS, only $6 \%$ at most, but its contagious rate is much higher compared to Ebola and SARS, which cause the disease fast spread across Wuhan city, soon in China and the world.

\section{Comparison of novel coronavirus and Atypical pneumonia}

First of all, the total number of SARS virus infections in 2003 was just over 8,000 in the world for the total duration of the epidemic. Wuhan's new coronavirus has caused more than 800 people getting infections in just one week. From the point of view of infectivity, the new coronavirus is 100 times more severe than the SARS virus. However, in terms of lethality, it appears that the death rate from SARS virus is five times of this statistics of the new coronavirus. But as we can see, the quick increase of infection numbers and the strong demand of patient beds has soon crushed the health care system. Needless to say, seventeen years ago, the level of medical care advancement in China was far weaker than it is now. Compounded with the effect of a medical resource run due to China's large population, the case number and death number of Corona virus did not manage under control in the first place. As a result, the infectivity and lethality are both greater of the new coronavirus than the SARS virus.

The virus has massive impact on people's day-to-day life. To give some examples, during the epidemic, students cannot go to school, workers cannot work, and recreational facilities cannot be opened. We all know the economy is built upon businesses, employees, and other participants, without everyone contributes on their own position, the economy cannot function. Especially during the pandemic outbreak, when everyone is expected to be quarantined at home, there is a huge demand for health care practitioners working day and night at the hospital to treat patients, scientists developing vaccines and medicines, as well as factories producing medical products to save lives. Not only need these facilities to run as usual, but also require them to achieve higher productivity and efficiency to meet the increasing demands. It is predictable that the health care industry needs heavy funding in order to meet the requirements.

\section{The impact of coronavirus on the global economy}

Rise above our individual's scope, when we look at the global scope, the coronavirus is leading to a global economic recession. Early estimates predicated that, if the virus become a global pandemic, most major economies will lose at least 2.4 percent of the value their gross domestic product (GDP) over 2020, several leading economists claimed that they already reduce their 2020 forecasts of global economic growth down from around 3.0 percent to 2.4 percent. To put this number in perspective, global GDP was estimated at around 86.6 trillion U.S. dollars in $2019-$ meaning that just a 0.4 percent drop in economic growth amounts to almost 3.5 trillion U.S. dollars in lost economic output. Worth noting that these predictions were made prior to COVID-19 becoming a global pandemic, and before the implementation of widespread restrictions on social contact to stop the spread of the virus. Since then, the US stock markets have suffered dramatic falls due to the outbreak, and the Dow Jones reported its largest-ever single day fall of almost 3,000 points on March 16, 2020 - beating its previous record of 2,300 points that was set only four days earlier. Based on these data, it can be seen that COVID-19's impact on the global economy is unprecedented, it also shows that the economic recession may continue further. As a student studying in the United States, I am witnessing the impact of the virus on both the United States and China. It is a great concern that the United States is now becoming the new epicenter of the outbreak, followed by the decline of the US economy. Despite of the U.S. officials rush to 
contain the spread of disease, the federal government is also grappling with the dramatic and unprecedented toll the epidemic has had on the economy, in four weeks, 22 million Americans have filed for unemployment benefits. Technical glitches prevented millions of Americans from receiving their stimulus checks from the U.S. Department of the Treasury. And the Small Business Administration, which supports U.S. entrepreneurs with loans and funding, run out of money for its Paycheck Protection Program. During the epidemic period, the unemployment rate in the United States has increased by $175 \%$. Unemployment will not only cause economic recession, but also cause some other social problems. When people lose their jobs, the long-lasting effects are not just on their income. Unemployment can cause further negative effects, such as workers' skills, education, even on their health-people who are unemployed may become easier to get sick. The reason behind is that social distancing bans people from seeing their families and friends, less caring for each other, and this sudden change of their norms can make people more emotional. Irrational decisions and amplified emotions are obviously reflected in the stock market's cliff-like decline and rocket rise. The US stock price fell by $45 \%$ in April, and it has been swung back after May. This phenomenon is very odd in the US economy history, even Warren E. Buffett quoted at his Berkshire Hathaway annual general meeting, "You can bet on the United States, but you must be careful about how you bet. Just because the market can do anything... No one knows what will happen tomorrow." Pessimistic investors are showing their concerns when they make investment decisions, arbitragers are actively trading in the market looking for short term gains, and optimistic investors are holding wait-and-see attitude. Therefore, in the next few months, the stock market is likely to continue a state of volatile up-and-down. But as the epidemic is slowly controlled under the global efforts, various government is loosening the restrictions on business activities, many companies have resumed operations, people are also developing ways to work from home. The stock market may show a trend of people's faith of wining this battle with Corona virus, and restore from negative growth to positive. China, as the first country discovered the new coronavirus, its economic recovery is performed quite differently compared to the US. There is no doubt that the impact of the virus on China's economy is huge. Chinese commerce ministry released key figures on COVID-19's impact on China's consumption, outbound investment and imports in the first two months of 2020 . The consumption reduction has hit me the most - especially catering, lodging and housekeeping industry sectors, as they have direct contact with consumers and very closely affecting myself, my families, and friends. In January and February, catering income went down by 43 percent. And in February, the income of lodging and housekeeping sectors both went down by at least 75 percent. Regarding China's imports in January and February, it was down nearly 300 billion U.S. dollars, or a 2.4-percent-dip year on year. Another shocking figure is about the consumption data of automobile, because automobile production is one of the important incomes of the Chinese economy, especially the processing of parts, it is a significant pillar of China's consumption, importing and exporting market. Only about 22 billion vehicles were sold in the first two months this year, down 42 percent from the same period last year. And only 310,000 units were sold in February alone, down nearly 80 percent. In the list of China's top ten countries with the largest exports going to China, seven of the nations' number of confirmed COVID19 cases have exceeded $1,000 \ldots$ That means more and more countries are suspending their production, their abilities of both supplying and buying are declining, the trading between borders are remaining inactive. The sectors of transportation equipment, energy-chemical industry, electro-mechanical have been hit particularly hard. All the data and statistics are pointing to the same conclusion, that the pandemic has brought big losses for the Chinese economy.

Also, when we look at the stock market, we can see the losses and costs bearing by the economic participants. In the epidemic, pessimism and panic emotions were shown on the stock market trading and investor decisions. On the first trading day after the Spring Festival, the stock market fell by $8 \%$. In the last three trading days, China Resources Land (real estate) fell 8.5\%, Longhu Group (Hong Kong stocks) fell 9.6\%, Xincheng Holdings (stock group 0 fell 7.0\%, Songcheng Performing Arts fell 11.1\%, Haidilao ( Food) fell by $9.2 \% \ldots$ all far exceeded the expected value. Different from the US stock market's dramatic fluctuations, China's stock market prices show a steady developing trend, especially in the health care sectors and consumption portfolios. This recovery is contributed by the measures Chinese government took soon after the claim of national first-level response in the event of a particularly major public health emergency or natural disaster in according to the National Natural Disaster Relief Emergency Plan. The first step was to block all transportations in and out from the center of the COVID-19 epidemic. The Chinese government quickly organized social resources and national resources to support the city of Wuhan since its closure. Around 40,000 medical staffs and teams were sent to assist on testing suspected cases, treating patients, and develop first-hand experience hand book and procedures for other Chinese cities to follow. Secondly, the Chinese government mobilized all possible financial institutions to support the battle with coronavirus at finance level. 27.3 billion yuan have been invested for epidemic prevention and control, establishing emergency hospitals, as well as vaccine and treatment medicine research and development. The financial policies continued after the epidemic situation has eased in mainland China, more and more financial institutions joined the progress of accelerating general public finances and implementing government funds in the field of infrastructure construction, especially the need to accelerate the issuance and placement of local government special bonds to give full play to infrastructure support. In addition, in this epidemic, the service industry has been hit hard, and many service industry companies have to close their doors and shut down. It is a timely policy launch for the service industry enterprises to take periodic tax relief measures to reduce their cash-flow burden. All these measures allow China's economy to recover quickly and stably. 


\section{National Response to the epidemic and help each other to tide over the difficulties}

Despite the huge economic blow, Chinese government has put its people's health and safety at its priority. The economy recovery after the COVID-19 outbreak has proven that the Chinese efforts are on the right direction. And China's methods for controlling the epidemic should be learned by other countries. As an example, Italy learned the Chinese approach and the epidemic was effectively controlled. Similarly, Italy tried to close cities and sent medical staff to various airports, stations, and ports to check if anyone is infected. Second, the Italian government informed the public about the virus and called on people to stay at home. Also, the Italian government put huge investment on temporary hospital construction and medical supply procurement. When there is a shortage of medical supplies, Italy government didn't hesitate to ask for help. China has played a significant role in helping other countries, not only at the national government level, but also at individual level. Many Chinese immigrants and overseas students living in Italy has helped, such as giving away and distributing facial masks, sanitizers, and thermometer. As the epidemic was brought under control, the factory resumed work and the recreational facilities were reopened, the Italian economy began to recover.

\section{Conclusion}

With optimistic outcome of Chinese economy recovery after the COVID-19 outbreak, and similar example of Italy, it remains to be a myth that whether the US economy is coming out from the recession completely. With the effective control of the epidemic and the recovery of the global economy, the U.S. economy may show a light of recovery in the coming months. But at the same time of implementing the epidemic prevention measures, the US is suffering from other crisis, such as unemployment turbulence, social issues, discrimination issues, and not to be ignored, election season is about to start, which can cause many uncertainties on the economy performance.

This global pandemic is a challenge to people all over the world. In the near future, there is hope that the epidemic will be controlled and over. Surely, we will continue to face challenges from one to another, but as long as we can put down our pride, respect the nature, and remember to always help out each other, we can together overcome all the difficulties.

\section{References}

[1] https://finance.sina.cn/2020-01-21/detail-iihnzahk5 643894.d.html

[2] https://baijiahao.baidu.com/s?id=165760514742774 $9435 \& w f r=$ spider $\&$ for $=p c$
[3] https://www.google.com.hk/amp/s/www.bbc.com/n ews/amp/business-51706225?client=safari

[4] https://www.americanprogress.org/issues/economy/ news/2020/03/06/481394/economic-impact-coronavirus -united-states-possible-economic-policy-responses/

[5] https://www.google.com.hk/amp/s/www.bbc.com/n ews/amp/business-51706225?client=safari

[6] https://news.cgtn.com/news/2020-03-27/COVID-19s-impact-on-China-s-trade-and-economy-in-Jan-andFeb--Pc9LIV8kDK/index.html

[7]h ttps://www.statista.com/topics/6139/covid-19-imp act-on-the-global-economy/\#dossierSummary_chapter 3 